\title{
All that glitters is not gold: the effect of top-down participation on conservation knowledge, attitudes and institutional trust in a Central Indian tiger reserve
}

\author{
Biljana Macura $^{1,2,3} \cdot$ Laura Secco $^{1} \cdot$ Elena Pisani $^{1} \cdot$ Andrew S. Pullin $^{2} \cdot$ \\ Victoria Reyes-García ${ }^{4}$
}

Received: 23 December 2014/ Accepted: 24 April 2016/Published online: 27 May 2016

(c) The Author(s) 2016. This article is published with open access at Springerlink.com

\begin{abstract}
Researchers and policymakers emphasize that people's involvement in forest management can secure their support of conservation initiatives. However, the evidence on the effectiveness of top-down participation is weak. This study uses cross-sectional household data from 16 villages in the buffer zone of Pench Tiger Reserve (Madhya Pradesh) in India to contribute to the evidence base of such assumption. Using a propensity score matching to control for observable bias, we evaluate the effects of two state-driven incentive-based participatory projects, i.e. the Joint Forest Management and Ecodevelopment, on selected social outcomes. Specifically, we measured local people conservation knowledge, biodiversity attitudes as well as trust in and satisfaction with the tiger reserve management authorities. We found that the effects of participatory management on conservation knowledge were positive, but negligible. We found no significant effects on local people's biodiversity attitudes,
\end{abstract}

Electronic supplementary material The online version of this article (doi:10.1007/s10113-016-0978-3) contains supplementary material, which is available to authorized users.

Biljana Macura

bmacura@gmail.com

1 Department of Land, Environment, Agriculture and Forestry, University of Padova, Viale dell'Università 16,

35020 Agripolis, Legnaro, Italy

2 Centre for Evidence-Based Conservation, School of Environment, Natural Resources and Geography, Bangor University, Deiniol Road, Bangor, Gwynedd LL57 2UW, UK

3 Present Address: Mistra-EviEM, Stockholm Environment Institute, Linnégatan 87D, 11523 Stockholm, Sweden

4 Institució Catalana de Recerca i Estudis Avançats (ICREA) and Institut de Ciencia i Tecnologia Ambientals, Universitat Autònoma de Barcelona, 08193 Bellaterra, Barcelona, Spain trust and satisfaction with the tiger reserve management authorities. Top-down and externally induced participation may explain our results. Our findings clearly indicate that the effectiveness of participatory conservation interventions is conditional on the level and nature of local participation. Top-down participatory projects may not be sufficient to generate local support of conservation and in some cases, they may even exacerbate local conflicts.

Keywords Decentralization - Integrated conservation and development · Joint Forest Management - People-wildlife interactions · Propensity score matching - Quasiexperiment

\section{Introduction}

Researchers and policymakers emphasize that people's involvement in forest management can secure their support of conservation initiatives (Brechin et al. 2002; Baral and Heinen 2007; Pimbert and Pretty 1995). The governance shift from socially exclusive conservation policies towards more inclusive ones started in the 1980s through community-based conservation and natural resource management, co-management arrangements, and efforts to integrate conservation and development (Reyes-Garcia et al. 2013). In these conservation governance arrangements, participation can be directed to achieve different objectives, such as manage conflicts among actors, provide legitimacy to resource managers, reinforce democratic culture, allow local voices to have a say in decisions concerning their livelihoods or improve decision-making by supplying local knowledge and values (Pretty 1995; Reed 2008; Young et al. 2013). However, such a diversity of people-centred conservation approaches shows varying levels of local 
people's involvement and control over management decisions, degrees of benefit sharing and the transfer of political power from the state to local communities. Despite such differences in using participation, there is evidence to support that people's participation in forest management and conservation can modify their behaviour and attitude towards biodiversity (Baral and Heinen 2007; Andrade and Rhodes 2012), improve conservation knowledge (Berkes 2009), and increase trust towards protected area managers (Richards et al. 2004; Young et al. 2013), ultimately leading to positive changes in the biodiversity outcomes of conservation efforts (see Persha et al. 2011).

In such a context, the relevant question is, "Which kind of participation is necessary to obtain a change in social and biodiversity outcomes?" A review of the literature shows that participation means different things to different people (Lawrence 2007; White 1996). The term "participation" has been used to refer to the attendance of a meeting so that participants can obtain information or benefits (passive participation), but also to self-mobilization and proactive engagement in decision-making over natural resources (active participation) (Agarwal 2001; Arnstein 1969; Pretty 1995; Reed 2008; White 1996). Participation can be an endogenous organic process led by self-motivated local groups independent of government as well as externally induced practice, promoted through governmental policy action and implemented by the bureaucrats (Mansuri and Rao 2013). However, these different types of people's involvement might not have the same effect on social and ecological conservation outcomes, i.e. conservation-related knowledge, attitudes and behaviour of local people, and biodiversity level (Agarwal 2001; Glaser et al. 2010; Persha et al. 2011).

Much of the literature on the topic has focused on bottom-up participatory initiatives, analysing self-organized groups of local people in managing resources (e.g. Ostrom 1990), but the research on the effects of externally induced participation on selected social and ecological outcomes is scarce. In this paper, we analyse two cases of state-driven participatory interventions to see whether there is any impact of top-down participatory approaches in conservation and natural resource management on social outcomes. We use cross-sectional household data collected in the buffer zone of the Pench Tiger Reserve (PTR), Madhya Pradesh in India, and a quasi-experimental research design to evaluate whether people's involvement in forest management and conservation through two state-driven incentive-based interventions, i.e. Joint Forest Management (JFM) and Ecodevelopment (ED) projects, affects people's conservation knowledge, biodiversity attitudes, and trust in and satisfaction with the park management authorities. Participatory approaches to forest management and conservation implemented in PTR, sometimes with geographical overlap, provide an ideal case to study: (1) whether local people's conservation knowledge and biodiversity attitudes vary between participants and non-participants and (2) whether the type of top-down participatory intervention (JFM or ED) matters in terms of the selected outcomes. To test potential pathways between people's involvement and conservation outcomes, we use findings of social psychology and attitudinal research (Ajzen 2001; St John et al. 2010) to create a theory of change that explains the links between the intervention, attitudinal change and conservation impacts (see Online Resource 1).

\section{Case study}

\section{Forest conservation and management projects in India}

Over the last three decades, two interventions of the central government have attempted to increase people's involvement in forest management and conservation in the humandominated forested landscapes of India: Joint Forest Management and Ecodevelopment projects.

JFM is a collaborative arrangement between local people and public entities to sustainably manage state-owned forests outside of PAs (Nayak and Berkes 2008). JFM is a top-down decentralization initiative (Kumar et al. 2014) initiated by the central government in 1990 and prompted by the National Forest Policy (GOI 1988) to recognize the value of local people's involvement in the natural resource management and biodiversity conservation. At the local level, JFM operates through committees installed in villages with assigned adjacent forest patches. In exchange for "social fencing", i.e. safeguarding, protection and improvement of the forest, the forest department provides villagers usufruct rights (negotiated), extraction of nontimber forest products and the share of revenue from a timber sale. Nevertheless, all the specific JFM arrangements depend on the states, and they need to follow the central government JFM rules. Now financed by the central government through the national afforestation policy scheme, the JFM initiative was initially partially funded by various foreign agencies, including the World Bank (WB) and the United Nations Development Programme, among others (Singh et al. 2011).

In India, Integrated Conservation and Development Projects (ICDPs) are known under the name of Ecodevelopment projects. ED projects are implemented around core zones of PAs with the main aim to conserve the core of the PAs from human impacts. They operate under the 1972 Wildlife (Protection) Act, which prohibits local people to acquire usufruct rights from the core zones of 
PAs. The India Ecodevelopment Project (IEDP) was approved in 1996 and was actively funded until mid-2004 by the Global Environmental Facility (GEF)/WB loancum-grant with the contribution from beneficiaries (local people), state and central governments. In total, USD 61 million was spent in five tiger reserves (protected areas governed by the tiger conservation programme of the Government of India called Project Tiger) and two national parks, out of which $54 \%$ was invested in the village ecodevelopment project component (World Bank 2007). Village ecodevelopment was designed "to reduce the negative impacts of local people on biodiversity and increase collaboration of local people in conservation" through: "[...] participatory microplanning [...], reciprocal commitments that foster alternative livelihoods and resource uses [...], special programmes for additional joint forest management, voluntary relocation and supplemental investments for special needs" (World Bank 2007, p. 2). After IEDP had ended, village ED continued to be part of the management plans of many PAs, especially of tiger reserves, but with reduced funding.

Although both projects aim at promoting people's involvement in conservation, there are differences between them. ED is designed to shift local forest-dependent people away from the forests (of the PA core zones) and find them alternative sources of livelihood (Badola 2000). JFM seeks to involve locals in the forest protection more actively where people have slightly more control over resource management; they patrol their assigned forest patch and can punish offenders. Yet, for both JFM and ED, it has been argued that they treat local people as "beneficiaries" and the control over the majority of decisions is with the forest department (Woodman 2002; Panigrahi 2006; Sarin et al. 2003).

Existing evaluations of the two participatory conservation interventions in India provide anecdotal evidence of their effectiveness in conservation. For example, a few case studies have produced some evidence that ED has no measurable effects on conservation due to (1) lack of genuine negotiation over benefits distribution between local communities and PA authorities, (2) a poor understanding of project objectives by local people, and (3) missing links between delivered incentives and obtained conservation outcomes (Mahanty 2002; Arjunan et al. 2006; Gubbi et al. 2008; Dejouhanet 2010). JFM has been more frequently evaluated than ED with mixed results (e.g. Kumar 2002; Murali et al. 2002; Damodaran and Engel 2003; Bhattacharya et al. 2010). However, such evaluations can only be considered anecdotal because such studies either measure only one type of outcome (mostly ecological) without removing rival explanations of the observed effects or do not adjust for selection bias occurring due to non-random assignment of such interventions (for a comprehensive review, see Shyamsundar and Ghate 2014). Rigorous studies that assess the effects of participatory conservation interventions with the causal inference are very rare (Lund et al. 2009; Miteva et al. 2012), except for some recent evaluation studies of the Integrated Conservation and Development Projects (ICDPs) (Morgan-Brown et al. 2010; Weber et al. 2011; Bauch et al. 2014), on devolution and community-based management and conservation (Jumbe and Angelsen 2006; Ameha et al. 2014), and on payments for environmental services (Hegde and Bull 2011). To our knowledge, credible evaluation studies of JFM and ED in India have not yet been conducted.

\section{Study site}

This research was conducted in the buffer zone of PTR, in Seoni and Chhindwara districts of Madhya Pradesh. PTR (Fig. 1) covers a total area of $1179.6 \mathrm{~km}^{2}$ divided between a core $\left(411.3 \mathrm{~km}^{2}\right)$ and a buffer $\left(768.3 \mathrm{~km}^{2}\right)$ zones. Although it was only included in Project Tiger in 1992, the area has been under protection since 1977. The core zone was officially proclaimed in December 2007 and the buffer in October 2010, but until 2013 the buffer zone remained under the control of three territorial divisions of the Madhya Pradesh forest department (MPFD) and was gradually handed to the wildlife wing of MDFP i.e. Pench Tiger Reserve authorities.

The study area is an undulating terrain with small hill ranges that supports three main forest types: southern Indian tropical moist deciduous forest (slightly moist), southern tropical dry deciduous forest (with teak Tectona grandis), and southern dry mixed deciduous forest. The core zone supports many species of high conservation concern and represents critical tiger habitat, which is an inviolate space "required for the sustenance of viable populations of tiger and other wild animals" where no human disturbance, habitation, resource extraction or agriculture is allowed (MOEF 2007, p. 1). Given that the Wildlife Protection Act governs PAs, extraction of forest resources is strictly prohibited from a PA core zone and there is no revenue sharing from such areas (except revenue from tourism). The buffer zone is a multiple use area with a lower degree of habitat protection where de jure rights for resources access and cultivation have been granted to local people.

Ninety-nine villages with around 60,000 people and around 60,000 cattle are located within the first five kilometres around the core zone. Twenty more villages are located in the rest of the buffer zone. More than $60 \%$ of the local people are Adivasi (i.e. original inhabitants), mostly belonging to the Gond tribal group. There is also a smaller percentage of the scheduled caste and other 


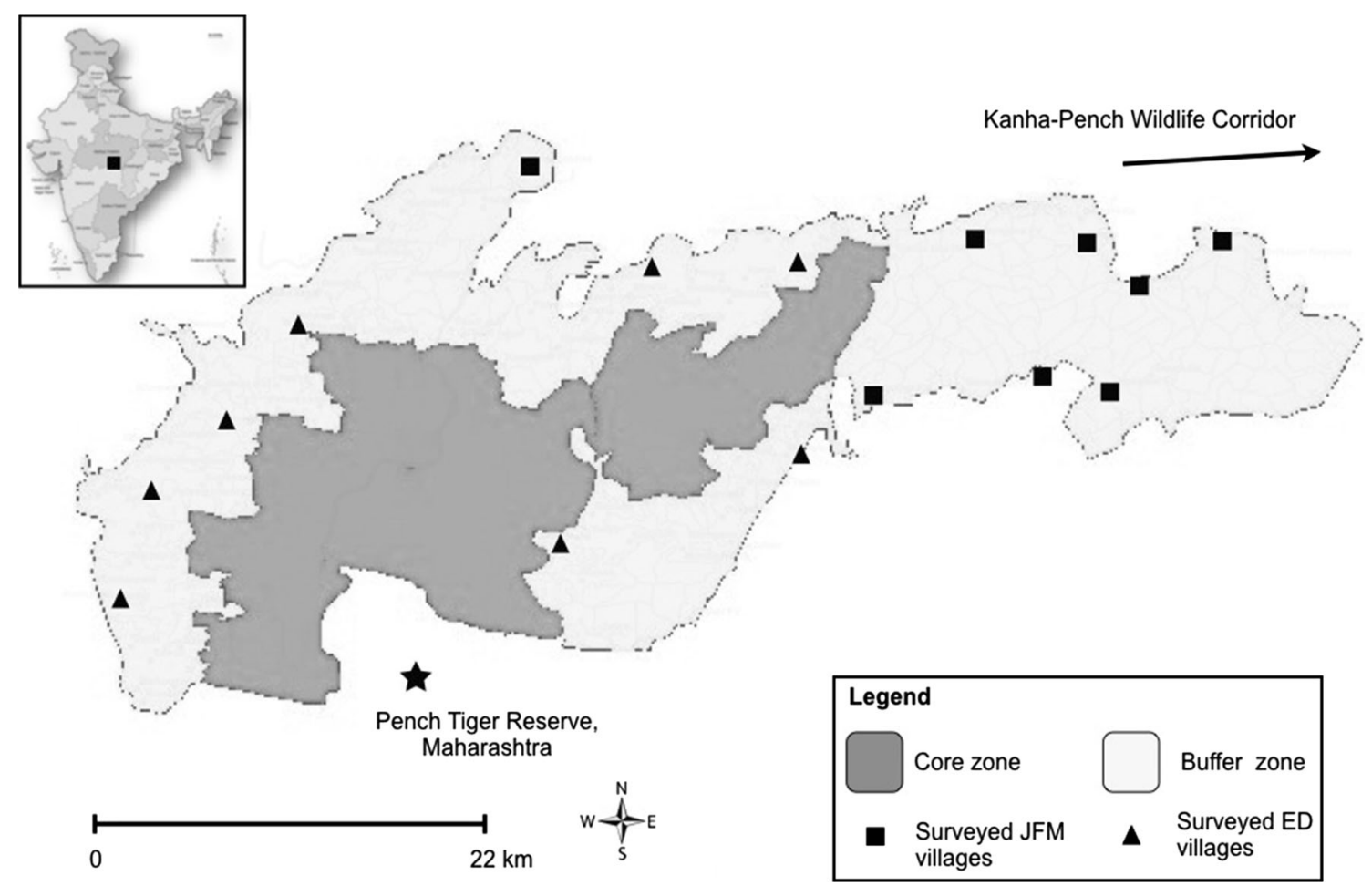

Fig. 1 Study location. Pench Tiger Reserve (Madhya Pradesh) with surveyed villages

backward caste. The main occupation of the local people is (subsistence) agriculture and wage labour (mostly forest related).

\section{Joint Forest Management around PTR}

The first JFM projects in Madhya Pradesh date back from 1991. There are two types of JFM committees depending on the forest quality: (1) Village Protection Committee (VPC) for reforestation of degraded lands with a forest cover density below $40 \%$ and (2) Forest Protection Committee (FPC) for forest protection with a cover density above $40 \%$. The forest quality also determines the revenue sharing through committees. Committees have a "general body" in which all the eligible village voters can (voluntarily) participate, and an "executive body" made of nine to eleven villagers, a secretary from the MPFD (usually a lower-rank forest officer) and a joint secretary from the village. The committee president is elected. The committee manages the funds, organizes the meetings, cooperates with the MPFD during forest fires, informs them about illegal activities, prepares and executes microplans with the help of the MPFD, patrols the forest and can punish offenders (MPFD 2014). Depending on the funding flow, villagers also receive household utensils that could decrease forest dependency (e.g. smokeless stoves, blankets and LPG connections). Most JFM committees in the Pench buffer zone are FPC.

\section{Ecodevelopment around PTR}

PTR was one of the selected sites where IEDP commenced in 1996-1997. Up to 2005, this project released 268.6 million Indian rupees (approx. USD 6.1 million) in PTR (Pench Tiger Reserve 2012). After IEDP funding ended in 2004/5, EDC remained in the villages albeit with considerably lower activities and intermittent funding coming in part from the federal and state funds allocated for the PA management activities, and in part from the share of tourism revenues (through the PTR development fund). From 2005 to 2011, 13.1 million rupees (approx. USD 282,000) were spent for ecodevelopment in the PTR, which is about 22 times lower than the amount spent in the period 1997-2005 (Pench Tiger Reserve 2012).

Ecodevelopment has been implemented through ecodevelopment committees (EDCs) in ninety-nine villages in the $5 \mathrm{~km}$ belt surrounding the PTR core zone. The structure and the role of EDCs are very similar to VPCs and FPCs. Involvement is voluntary. The EDC general body is composed of all the eligible village voters. The executive body is composed of a group of nine to eleven villagers including the elected president and a secretary from the 
PTR who usually is a lower-rank forest officer. Apart from the bookkeeping, informing PTR staff about illegal activities, planning and execution of a microplan with help of PTR staff, the EDC provides household-level benefits and various assets to interested villagers (i.e. pressure cookers, gas cylinders and stoves with improved efficiency, dungpowered biogas plants, bicycles, sewing machines and field banding). According to the project plan, beneficiaries need to contribute $7-25 \%$ of the household asset price (to develop a sense of "ownership"). EDC also provides village-level infrastructure (i.e. ponds, wells, stop dams, electric pumps for agricultural intensification, roads, community halls and stalls for meetings, game-proof wall). The objective of these provisions is to decrease pressure on the forests and to create alternative (non-forest) livelihoods.

After the IEDP funding ended, the PTR management authorities have been occasionally distributing gas cylinders, stoves, pressure cookers, organizing IT classes, and conducting some minor activities in the villages. Although the supply of these incentives theoretically depends on the local demand, provision of benefits is limited by the availability of PTR funding (National Tiger Conservation Authority is a supervisory and coordination body of Project Tiger that approves a plan of ED expenditure). The fund availability conditions EDC activities, meeting frequency (once or twice per year in some villages) and regularity of benefit distribution (sometimes once per year). Thus, not all households in a targeted village receive benefits, i.e. occasionally around $10 \%$ of all the households in a village receive some assets.

\section{Methods}

\section{Research design}

Fieldwork was carried out between January and May 2014. We implemented a quasi-experimental design with two-stage, random stratified and systematic sampling. In total, we sampled 16 villages in the buffer zone of the PTR. We selected villages according to several criteria. First, half the villages selected had benefited from JFM and the other half from ED projects. Second, we took into account the intensity with which the projects were applied: from a list containing all the ED villages in the park surrounding, we randomly selected four villages with high and four villages with a low amount of received household- and village-level benefits. Using data from Census of India (2011), we matched the JFM-participating villages with the ED-participating villages on the population size, ethnic and caste composition, literacy rate, the number of non-workers. We also matched villages on proximity to a forested area. Sixty per cent of sampled villages were located within five kilometres from the core zone. On average, we surveyed 20 households in each village. First, we obtained a village map (or created one ourselves) with marked and numbered households. Second, among the first ten households counting from a village entrance, we randomly selected a starting household (using random number generator function in Excel spreadsheets) and sampled subsequent households at intervals determined by a village size (Bernard 2006). If there was more than one street in a village, we repeated this procedure for every street.

We carried out face-to-face structured questionnaires implemented by five non-local enumerators conversant in Hindi (Madhya Pradesh official language) from a professional agency for social research. Enumerators received a thorough four-day training to understand research objectives, conservation context and questionnaires. The questionnaires were written in English, translated and conducted in Hindi and pretested in two buffer zone villages, after which unclear and ambiguous questions were removed. The data from the pilot were excluded from the final results. Before administering questionnaires, enumerators obtained participant's prior free informed oral consent. Out of 320 collected questionnaires, 302 contained complete data and were included in the final analysis. The questionnaires contained closed-ended and openended questions and included demographic and socioeconomic characteristics of the household, together with: (1) perceptions of the ED or JFM project, (2) knowledge of the tiger reserve rules and location, (3) attitudes towards biodiversity and (4) trust in and satisfaction with park authorities.

Since a household head represents a household and is the one who makes household-level decisions (especially regarding project involvement and accruing benefits, interaction with the FD, etc.), we administered questionnaires to household heads. If neither the male nor the female household head was present (33.8\% of the sample), we administered questionnaires to a person older than 21 (as younger household members might not have remembered past activities of ED and JFM projects). Both ED and JFM operate at a household and a village level, and we collected household- and village-level data.

In addition to the questionnaires, we also collected rich contextual and historical information on the projects' past and current functioning through over $30 \mathrm{semi}$-structured interviews with committee members and MPFD staff. We asked about activities of different internal and external actors, possible conflicts between them, frequency and attendance of meetings, the level of local people's engagement in the decision-making process, the distribution and demand of the village-level and household-level assets. On average, each interview lasted for about an hour. 


\section{Hypotheses and effects: from involvement to behavioural change}

Following our theory of change, to evaluate the effects of top-down participation we measure several intermediary effects through which participation can theoretically influence local people's behaviour and possibly affect conservation success (see Fig. 1 in Online Resource 1). Specifically, the selected outcomes include: (1) conservation-related knowledge; (2) attitudes towards biodiversity, particularly, towards forests, tigers, and other wildlife; (3) attitudes towards PTR managers and (4) trust in PTR managers (Table 1).
As researchers have argued that people's involvement in forest management and conservation produces pro-conservation behavioural changes (Andrade and Rhodes 2012; Persha et al. 2011), we expect that people living in households that are included in any forest conservation programme (either JFM or ED) would have more conservation knowledge and more positive attitudes towards biodiversity than people living in non-participating households (H1).

Additionally, if the differences in involvement matters and if the intensity of people involvement in conservation was higher in ED-participating than in the JFM-participating villages, we expect to find more conservation-

Table 1 Measured outcomes and related questions for participant (both ED and JFM) and non-participant households

Measured constructs Constituting questions, scores and rating scales

A. Conservation knowledge ${ }^{\mathrm{a}}$ Do you know about Pench Tiger Reserve?-Yes (1)/No (0)

Do you clearly know where are the boundaries of the core zone?-Yes (1)/No (0)

Do you clearly know where are the boundaries of the buffer zone?-Yes (1)/No (0)

What is your definition of the buffer zone?-No knowledge (0), fair understanding (1), good understanding (2)

Which activities are banned in the core zone?-No knowledge (0), knows 1 rule (1), knows 2 rules (2), knows 3 rules (3)

Why do you think these activities are banned in the core zone?-No knowledge (0), fair understanding (1), good understanding (2)

Which activities are allowed in the core zone?-No knowledge (0), fair understanding (1), good understanding (2)

B. Attitudes towards biodiversity $^{\mathrm{C}}$

\section{Attitudes towards PTR} authority $^{\mathrm{e}}$

D. Trust in PTR authority
Scale reliability coefficient $(\alpha)$ : 0.8253 (for $\mathrm{H} 1$ ) and 0.8085 (for $\mathrm{H} 2$ ) $^{\mathrm{b}}$

Do you like or dislike:

Tiger?-Strongly dislike (1), dislike (2), neutral (3), like (4), like very much (5)

Other wild animals?-Strongly dislike (1), dislike (2), neutral (3), like (4), like very much (5)

Forests?-Yes (1)/No $(0)^{\mathrm{d}}$

Scale reliability coefficient $(\alpha)$ : 0.5475 (for $\mathrm{H} 1$ ) and 0.5402 (for $\mathrm{H} 2$ )

Taking everything into account, how satisfied are you with the Tiger Reserve management authority?-Very unsatisfied (1), unsatisfied (2), neutral (3), satisfied (4), very satisfied (5)

How much do you trust the Tiger Reserve management authority to work in your interest? - Not at all (1), not very much (2), neutral (3), a fair amount (4), a lot $(5)^{\mathrm{f}}$

\footnotetext{
${ }^{a}$ Based on Olomí-Solà et al. (2012). Answers from open-ended questions 4, 5, 6 and 7 are coded into the different levels, assigning 0 score if a respondent did not know or gave the wrong answer and 1 for every correct answer. Only one correct answer given by a respondent was coded as "fair knowledge/fair understanding", and two correct answers were coded as a "good knowledge/good understanding". Final knowledge score is a sum of all the individual item scores divided by the highest aggregated score $(=8)$

${ }^{\mathrm{b}}$ We assume that the awareness of park rules is more important for the compliance and conservation-oriented behaviour than the sole knowledge of the PTR existence and its location. Therefore, we have assigned different weights to the constituting questions of the conservation knowledge indicator

${ }^{c}$ Attitude is a summary evaluation, a level of a favour or disfavour towards an attitude object (Ajzen 2001). In our case attitude objects are tiger, other wild animals, forests or park management authority. Following previous research on the topic (Macura et al. 2011; Allendorf and Allendorf 2013; Ajzen 2001) we measured attitudes through enquiries about liking or disliking attitude object

${ }^{\mathrm{d}}$ Collapsed to $1 / 0$ format as $89.4 \%$ participants liked forests, i.e. assigned score 4 to the statement

e Attitudes and trust towards PTR management authority are relevant only for the H2 as people who are not participating neither in the JFM nor in the ED most probably do not have frequent encounters with the PTR managers

${ }^{\mathrm{f}}$ Based on Baral (2012). According to encapsulated interest theory, trust is relational and can be defined as "a tripartite relationship in which A trusts B with respect to X" (Baral 2012, p. 43)
} 
related knowledge, more positive attitudes towards biodiversity, and an overall better relationship (attitudes and trust) with PTR managers in ED-participating than in the JFM-participating households (H2).

\section{Empirical strategy}

We estimated the causal effects of involvement in the statedriven top-down participatory initiatives on selected outcomes in two different ways. First, we calculated the effects of the involvement in the ED and the JFM versus no involvement, and second we calculated the effects of the involvement in the ED versus involvement in the JFM. For every outcome, we measured the average impact of projects on their participants. Hence, we focused on the average treatment effect on treated (ATT), defined as the difference between the average observed effect with the involvement and the average counterfactual without the involvement or with the involvement in an alternative project (Dugoff et al. 2014; Caliendo and Kopeinig 2008) (Eq. 1):

$\mathrm{ATT}=E\left(Y_{i}-Y_{0} \mid P=1\right)=E\left(Y_{i} \mid P=1\right)-E\left(Y_{0} \mid P=1\right)$

where $P=1$ denotes project participation, $Y_{i}$ is the outcome of the participant household, $Y_{0}$ is the counterfactual outcome or the outcome of the same household if it had not participated in the project (Ameha et al. 2014).

However, the obvious evaluation problem is that the counterfactual $\left(E=\left(Y_{0} \mid P=1\right)\right)$ is unobservable (a participant cannot be a non-participant at the same time), and thus, the researcher has to choose an appropriate substitute to estimate it (Caliendo and Kopeinig 2008). As in conservation projects participants are not randomly assigned to the treatment or they do not have an equal opportunity to participate, selection bias or other factors that determine the decision to participate might influence the observed effects (Ferraro 2012). To overcome these issues and to create a credible comparison, we apply the propensity score (PS) matching (a statistical nonparametric method) for our calculations. PS (Eq. 2) is a predicted probability of participating in a project conditional on a set of observed covariates $(X)$ (Rosenbaum and Rubin 1983). PS is specified through a binary choice modelling (probit or logit).

$\operatorname{Prob}(X) \equiv \operatorname{Pr}(P=1 \mid X)=E(P \mid X)$

For testing H1, we created a treatment sample (dependent variable $=1, \quad N=212$ ) that includes those households that (1) received household assets through either ED or JFM; and/or (2) have been members of the ED or JFM committees; or (3) were well aware of the village-level activities executed through the aforementioned projects, even if they had not directly received any household assets. Namely, all sampled villages were exposed to the activities of either of the two projects, and if not for their household, villagers have received some development help for their village (a pond, a water tank or road construction and repair, and similar). Therefore, household heads that were aware and perceived some benefits from these village-level activities were placed in the treatment group. Households that did not have any knowledge about any of the two projects and who never received any benefits composed the control sample (dependent variable $=0, N=91$ ). We did not distinguish between households who received benefits before and households who also received benefits after the GEF/WB funding ended. For testing H2, we analysed a subsample of the participants and evaluated differences in the effects of $\operatorname{ED}(1, N=118)$ versus JFM $(0, N=81)$.

We assume that the involvement in either of the two projects (H1) will be driven by different factors (H2). Therefore, we have two different sets of covariates to fit two propensity specification models (see Table 1 in Online Resource 2). To model involvement under H1, we combined the following covariates: household size and wealth index, household head's gender, education and age, received compensation for crop raiding and cattle loss, village distance to the nearest forested area, and the PTR core zone proximity. To model involvement under $\mathrm{H} 2$, we included the following covariates in the model: household head's gender and education, monthly household cash income per person, electricity, livestock possession, cattle loss to wildlife, a participation of any member of a household in non-forest-related groups and village distance to the nearest forested area.

The choice of covariates was based on theoretical considerations, results from previous research and data on projects' design and activities (see Online Resource 2). To make sure covariates are not affected by the treatment, we choose covariates that are stable or deterministic with respect to time (Caliendo and Kopeinig 2008). Despite some minor local differences, economic, social and institutional settings of all the sampled households are very similar as data come from villages located relatively close to each other (within the radius of approx. $70 \mathrm{~km}$ ), all villages are adjacent to a forest, and they have similar economic and cultural background. Moreover, all data were collected at the same time with the identical questions to measure the effects for non-participants, ED and JFM participants (see Table 1). Therefore, our study design context complies with the criteria for inference from observational studies with low (or no) bias (Heckman et al. 1998; Ferraro and Miranda 2014). The probit and logit models, a justification for variable selection for both models, information on matching algorithm and balance diagnostics are available in Online Resource 2. 


\section{Results}

\section{The sample before matching}

We sampled 302 households in 16 villages, out of which 210 households had participated in either of the two projects, and 92 households were controls (non-participants). The subsample of participants is composed of 81 JFMparticipating households and 118 ED-participating households. Table 2 shows the descriptive statistics for the unmatched samples.

In the total sample, average household size was 5.36 ( $\mathrm{SD}= \pm 1.775)$ with $15.23 \%$ of female heads. A little over $45 \%$ household heads did not have formal education. Thirty-eight per cent of households reported a loss of livestock to wild animals and $36.42 \%$ received compensation (at least once) for crop raiding or cattle loss. The household wealth index was low $(0.02 \pm 1.013)$. Average monthly cash income was 873INR (approx. USD 14.8 in April 2014) per person in a household. The majority of families owned livestock $(74.83 \%)$ and had electricity in their house $(90.73 \%)$. Only a small percentage of households participated in non-forest-related groups $(14.9 \%)$. Average distance from village to a nearest forest area was $1.34 \mathrm{~km}( \pm 0.695)$.

When compared to the sampled non-participating households, the monthly cash income and household wealth index of participants were significantly higher (no households reported ED or JFM to be their primary employment source). A significantly higher percentage of sampled participating households also received compensation for cattle or crop loss and belonged to the villages settled closer to a forested area and to the PTR core zone.

Sampled ED-participating households had a significantly smaller percentage of female household heads, livestock ownership, livestock loss to wildlife and a lower proportion of participation in non-forest-related groups than JFM-participating households. A significantly lower number of sampled ED-participating households had electricity and higher monthly cash incomes. Their villages were significantly closer to the core zone but slightly more distant (for $460 \mathrm{~m}$ on average) from a nearest forested area than surveyed JFM-participating households.

In the total unmatched sample, conservation knowledge was low, with an average score of 0.35 out of 1 . Biodiversity attitudes were positive: $63.91 \%$ of surveyed households had positive attitudes towards tigers and $54.31 \%$ towards other wildlife (sum of levels 4 and 5). A little more than $98 \%$ liked forests (this category was collapsed from a scale of $1-5$ to $1 / 0$ format as $89.4 \%$ surveyed households assigned score 4 to this attitude statement). Responses to questions concerning satisfaction and trust towards park authorities could not be considered as pertinent for the overall sample, as the majority of nonparticipant households could not respond to these questions.

An unmatched sample of participating households had significantly higher knowledge scores ( 0.42 out of 1$)$ than non-participating households (0.19). Other outcomes were not significantly different.

In sampled ED-participating households, conservation knowledge was significantly higher than in surveyed JFMparticipating households $(0.15$ and 0.64 out of 1 , respectively). Biodiversity attitudes were not significantly different. Average scores of satisfaction and trust towards park authorities were significantly lower in ED-participating households, where $33.89 \%$ of surveyed households were satisfied with PTR, in comparison with $45.68 \%$ of JFM-participating households (levels 4 and 5). Almost $36 \%$ of ED-participating households trusted PTR to work on their interests, as opposed to $46.91 \%$ of JFM-participating households (levels 4 and 5).

\section{Average effects of involvement in ED and JFM (H1)}

When measuring the effect of involvement in either of the projects, the conservation knowledge score was the only significantly different outcome between matched participating and non-participating households (0.14, $\mathrm{SE}=0.052, \quad t$ stat $=2.78$ ) (Table 3 ). The participant knowledge score was on average low (0.42 out of 1$)$, but still almost two times higher than the non-participant knowledge score $(0.28)$.

Differences in attitudes towards tigers, other wildlife and forests were insignificant. For participating households, attitudes towards tiger and other wild animals averaged 3.41 and 3.23 (on a scale of 1-5), respectively. In non-participating households, attitudes towards tigers and other wildlife were lower, but not statistically different (3.18 and 3.02, respectively). Attitudes towards forests were consistently very positive and $99 \%$ of respondents in both samples stated that they like forests.

\section{Average effects of involvement in ED compared to JFM (H2)}

The only significant difference between households involved in ED and JFM in the matched sample relates to their knowledge about conservation (Table 4). Here the difference is even higher than the one from $\mathrm{H} 1$ (mean $=0.41, \quad \mathrm{SE}=0.056, \quad t \quad$ stat $=7.3$ ). Average knowledge score of ED-participating households was relatively high ( 0.63 out of 1 ), while the score of JFM-participating households was almost three times lower (0.22). 


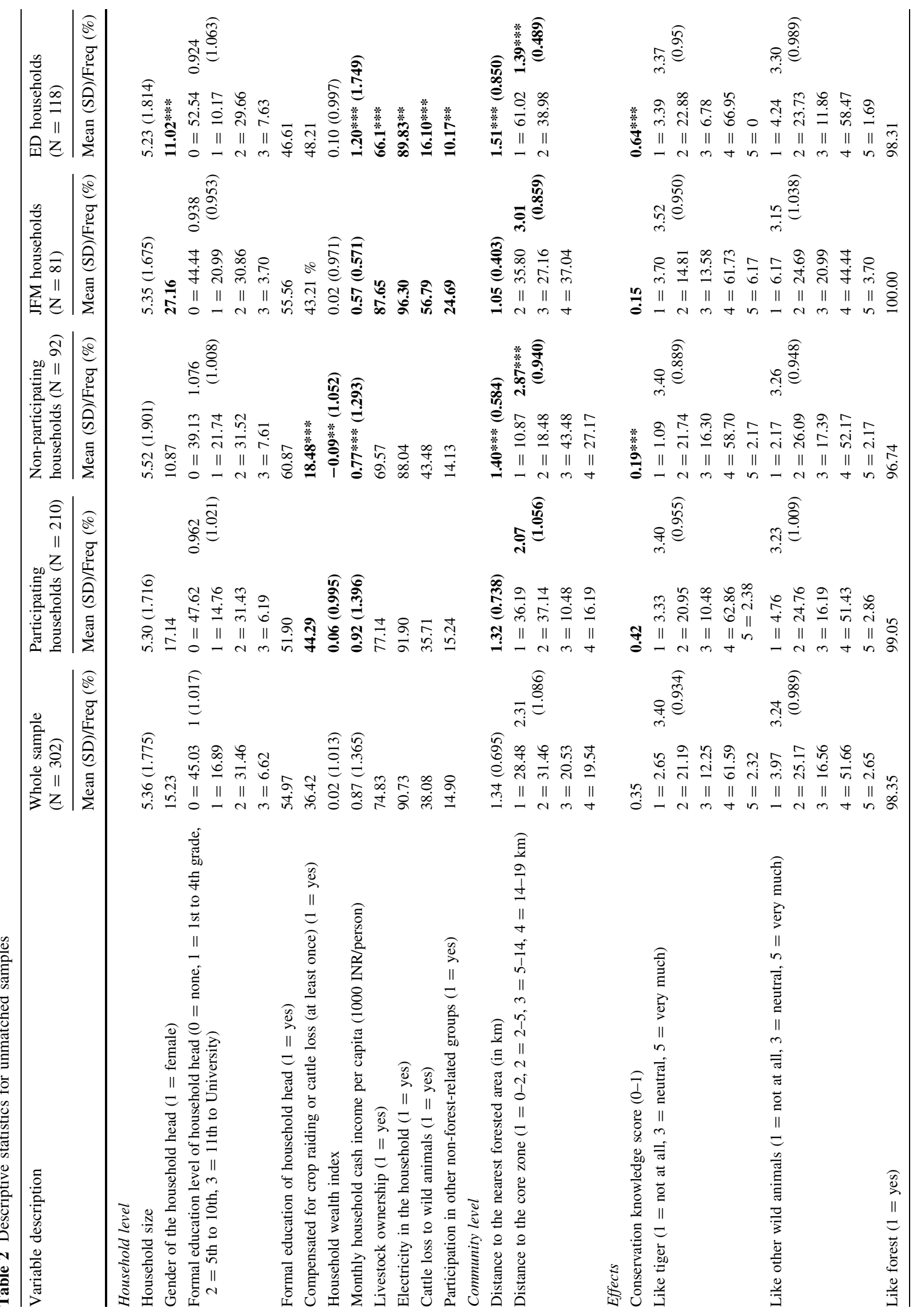




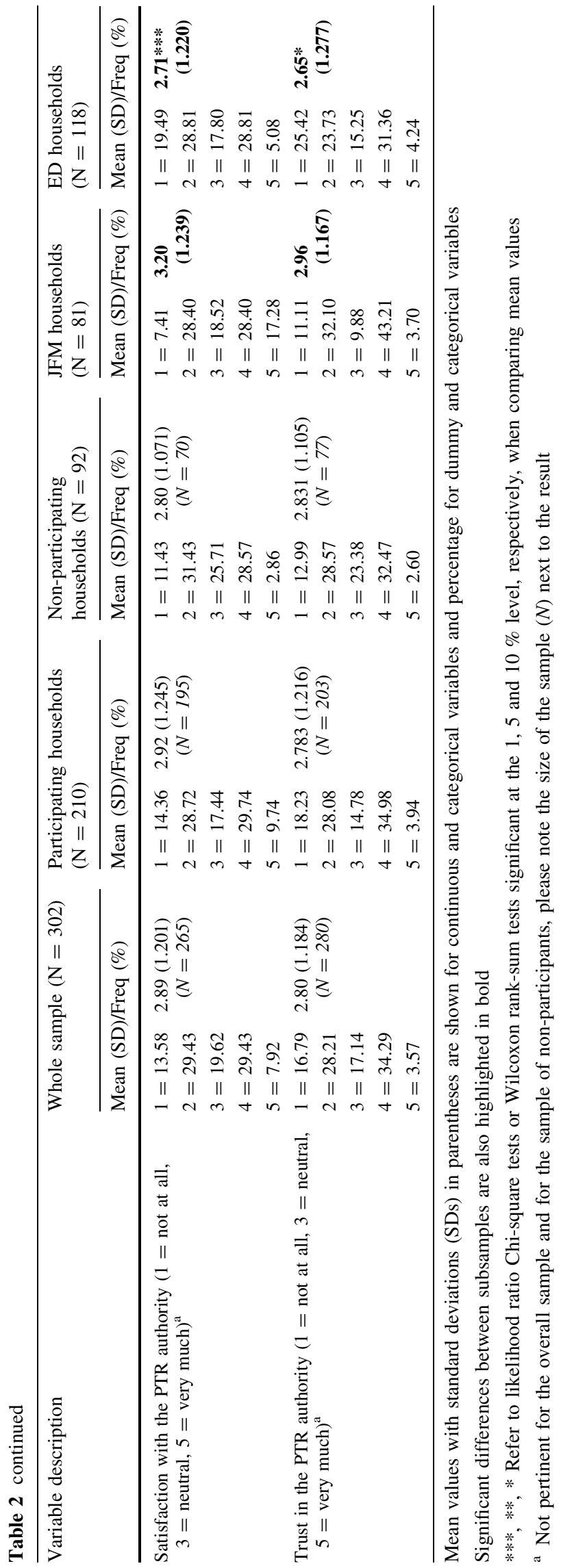

Differences in attitudes towards tigers, other wildlife and forests were insignificant in this subsample too. In EDparticipating households, attitudes towards tiger and other wildlife averaged 3.44 and 3.30 (on 1-5 scale), respectively. In JFM-participating households, attitudes towards tiger were higher (3. 48 on a scale of 1-5), but attitudes towards other wildlife were lower (3.04). Attitudes towards forests were very positive in both subsamples $(0.98$ and 1 out of 1 in ED- and JFM-participating households, respectively). JFM-participating households were slightly more satisfied with and trusted in the PTR authorities. However, these differences in satisfaction $(0.46$, $\mathrm{SE}=0.321, t$ stat $=1.42)$ and trust $(0.26, \mathrm{SE}=0.312$, $t$ stat $=0.84)$ were not statistically significant.

\section{Discussion}

\section{Caveats}

Before we discuss our findings, we identify caveats of this work. (1) Although propensity score matching can produce correct estimates even with small sample sizes (see Pirracchio et al. 2012), small statistical power may still impede detection of small but significant effects. (2) As with every matching exercise, our results depend on the PS model specification (Caliendo and Kopeinig 2008). The matching estimator might be biased if the project participation is driven by criteria other than ones observable to a researcher. Although we attempted to include all observable covariates in our PS model (by informing ourselves about projects' background and accounting for alternative explanations of measured effects), we still might have omitted some factors that simultaneously influenced involvement and measured outcomes. To minimize bias from unobserved variables, we ran different model specifications with all potential variables, and we found that our results remained robust with one exception: the significance of the variable on attitudes towards tiger changed for the H1-related model. (3) Our assessment of project effects is based on the respondents' perceptions, a measure which might be considered less objective. Our proxy variables of biodiversity attitudes, trust and satisfaction towards PTR authority are coarse estimates, as they were measured with a single question. In-depth understanding of the complex issues such as biodiversity attitudes, institutional trust or satisfaction requires qualitative or longitudinal data to reflect the field situation more realistically. In this study, we use qualitative interview data to explain and complement survey findings. (4) We collected survey data on conservation knowledge and attitudes from one household member. Since the specific living context (such as a household) conditions respondent's answers, we assumed 
Table 3 Effects of participation (in either ED or JFM) versus no participation (H1) (ATT)

\begin{tabular}{|c|c|c|c|c|c|c|}
\hline Variable & Sample & $\begin{array}{l}\text { Participating } \\
\text { households }\end{array}$ & $\begin{array}{l}\text { Non-participating } \\
\text { households }\end{array}$ & Difference & SE & $T$ stat \\
\hline \multirow[t]{2}{*}{ Conservation knowledge score $(0-1)$} & Unmatched & 0.42 & 0.19 & 0.24 & 0.038 & 6.23 \\
\hline & ATT & 0.42 & 0.28 & 0.14 & 0.052 & $2.78 * * *$ \\
\hline \multirow{2}{*}{$\begin{array}{l}\text { Like tiger }(1=\text { not at all, } 3=\text { neutral, } 5=\text { very } \\
\text { much })\end{array}$} & Unmatched & 3.40 & 3.39 & 0.01 & 0.117 & 0.07 \\
\hline & ATT & 3.41 & 3.18 & 0.23 & 0.174 & 1.33 \\
\hline \multirow{2}{*}{$\begin{array}{l}\text { Like other wild animals }(1=\text { not at all, } \\
3=\text { neutral, } 5=\text { very much })\end{array}$} & Unmatched & 3.23 & 3.26 & -0.03 & 0.124 & -0.26 \\
\hline & ATT & 3.23 & 3.02 & 0.20 & 0.185 & 1.09 \\
\hline \multirow[t]{2}{*}{ Like forest $(1=$ yes $)$} & Unmatched & 0.99 & 0.97 & 0.02 & 0.016 & 1.45 \\
\hline & ATT & 0.99 & 0.99 & 0 & 0.034 & 0 \\
\hline
\end{tabular}

Mean differences are shown for both matched and unmatched samples

Ten treated cases (3.3\% of the total sample) were dropped from this comparison due to a lack of common support and were not included in ATT estimation

*** Stands for significance at $1 \%$ level

Table 4 Effects of household participation in ED versus participation in JFM (H2) (ATT)

\begin{tabular}{|c|c|c|c|c|c|c|}
\hline Variable & Sample & $\begin{array}{l}\text { ED-participating } \\
\text { households }\end{array}$ & $\begin{array}{l}\text { JFM-participating } \\
\text { households }\end{array}$ & Difference & SE & $T$ stat \\
\hline \multirow[t]{2}{*}{ Knowledge score $(0-1)$} & Unmatched & 0.64 & 0.15 & 0.49 & 0.031 & 15.84 \\
\hline & ATT & 0.63 & 0.22 & 0.41 & 0.056 & $7.3 * * *$ \\
\hline \multirow{2}{*}{$\begin{array}{l}\text { Like tiger }(1=\text { not at all, } 3=\text { neutral, } 5=\text { very } \\
\text { much })\end{array}$} & Unmatched & 3.37 & 3.52 & -0.15 & 0.137 & -1.06 \\
\hline & ATT & 3.44 & 3.48 & -0.04 & 0.247 & -0.16 \\
\hline \multirow{2}{*}{$\begin{array}{l}\text { Like other wild animals }(1=\text { not at all, } 3=\text { neutral, } \\
5=\text { very much })\end{array}$} & Unmatched & 3.30 & 3.15 & 0.15 & 0.146 & 1.02 \\
\hline & ATT & 3.30 & 3.04 & 0.25 & 0.252 & 1 \\
\hline \multirow[t]{2}{*}{ Like forest $(1=$ yes $)$} & Unmatched & 0.98 & 1 & -0.02 & 0.014 & -1.18 \\
\hline & ATT & 0.98 & 1 & -0.02 & 0.013 & -1.42 \\
\hline \multirow{2}{*}{$\begin{array}{l}\text { Satisfaction with the PTR authority }(1=\text { not at all, } \\
3=\text { neutral, } 5=\text { very much })\end{array}$} & Unmatched & 2.71 & 3.20 & -0.49 & 0.177 & -2.74 \\
\hline & ATT & 2.72 & 3.18 & -0.46 & 0.321 & -1.42 \\
\hline \multirow{2}{*}{$\begin{array}{l}\text { Trust in the PTR authority }(1=\text { not at all, } \\
3=\text { neutral, } 5=\text { very much })\end{array}$} & Unmatched & 2.65 & 2.96 & -0.31 & 0.178 & -1.74 \\
\hline & ATT & 2.66 & 2.92 & -0.26 & 0.313 & -0.84 \\
\hline
\end{tabular}

Mean differences are shown for both matched and unmatched samples

Six treated cases ( $3 \%$ of the total sample) were dropped from this comparison due to a lack of common support and were not included in ATT estimation

*** Stands for significance at $1 \%$ level

that these answers could represent the whole household. However, we are not in a position to evaluate whether there are individual-level differences within households. (5) Responses to our survey questions might be biased because interviewees tend to give socially desirable answers and we might have over-reported or under-reported the results. Nevertheless, we have taken all the necessary measures to gain the interviewees' trust so they feel more comfortable expressing their genuine opinions: we clearly explained research objectives, guaranteed and respected confidentiality and anonymity, and we asked sensitive questions using the neutral wording. (6) We cannot generalize our findings for all of India, as we study a single PA that is not particularly known for either success or the 
failure of the ED project. Despite all the limitations of our data, we argue that our results provide interesting food for thought that can help guide future research in the field and contribute to the limited evidence base on top-down participation effects. Future research on the topic should aim for greater statistical power, have robust baseline data and include more detailed proxies of trust, conservation attitudes and behaviour. Future evaluations should be further improved by measuring not only social effects, but also incorporating biophysical indicators of the impact, such as forest cover change. In the following paragraphs, we discuss our survey findings supported by the qualitative data from interviews with different PTR actors.

\section{The effect of top-down participation}

Although literature suggests that people's involvement in conservation might have a positive effect on social and ecological outcomes (e.g. Andrade and Rhodes 2012), our findings imply that the top-down externally induced participation might not actually be effective in delivering required conservation outcomes. Our results also suggest short-term legacy of these interventions. Specifically, we found that involvement in the two state-driven participatory projects had an effect on the level of conservation knowledge only. Furthermore, the magnitude of the effect was low, as knowledge about PTR existence; location and regulations were relatively weak in the matched subsamples. We have not found effects of involvement on people's conservation attitudes.

A small effect of top-down participation has several implications for the analysed system. The low conservation-related knowledge might act as an obstacle for engagement in a pro-conservation behaviour and rule compliance (Schultz 2002). A closer look at the knowledge variable reveals that only $21 \%$ participant and $10.9 \%$ non-participant households could define "buffer zone". Our qualitative interviews support findings of the survey and showed how recent administrative changes connected to the buffer zone expansion (in 2013 and 2014) created some confusion, wherein locals were not aware of how these changes might affect their rights and they feared forced relocation. We argue that this finding reflects low activity level of ED and JFM committees. If they were fully functional co-management institutions, they would probably facilitate interactions between locals and the PTR staff and act as an arena for exchange and co-production of knowledge, trust building and conflict resolution (see Berkes 2009).

We found no effect of involvement on local people's biodiversity attitudes. Our findings concur with another independent ED evaluation from Periyar Tiger Reserve (Gubbi et al. 2008), where conservation attitudes could not be explained by the project involvement but by previous experience of human-wildlife conflict, among other factors. In our study, local people's attitudes towards biodiversity were overall positive. However, locals hardly perceived benefits of conservation interventions. Data from interviews suggest that some local people perceive that good enforcement and the ban on resource extraction from the PTR core zone have resulted in higher wildlife abundance and intensification of crop raiding in adjacent agricultural fields. Moreover, villagers seemed frustrated to frequent crop-raiding incidents. The everyday fight for subsistence, such as defending fields from wild animals, does not permit locals to have any free time for other activities (Interview, forest villager, January 2014) and therefore no time to attend EDC meetings. Locals involved in $\mathrm{ED}$ project frequently perceive $\mathrm{ED}$ provisions to be insufficient to offset these big costs connected to both park access restrictions and agricultural losses (EDC member, February 2014). They often demanded to fence their fields and to be better compensated from crop raiding. Our findings suggest that the top-down participation coupled with high conservation-related costs would not be able to generate sufficient support of locals towards conservation practices. In another study, top-down participation in formal forest conservation and management groups was even negatively associated with peoples' attitudes towards biodiversity (Macura et al. 2011). Moreover, dissatisfaction with management policies and practice could easily translate into a local collective action against conservation (see Rastogi et al. 2014).

\section{The difference a project makes}

When comparing the outcomes of ED and JFM projects, we found that despite the aforementioned differences in projects' objectives and design, there is possibly no real distinction between the two projects at the implementation level and vis-à-vis the intensity and nature of participation. Thus, we found no difference between the ED- and JFMparticipating households, except in the level of conservation knowledge. As hypothesized, ED-participating households have higher levels of knowledge than the JFMparticipating households and this is not surprising. Villagers further away from the PTR might not necessarily know the PTR boundaries or the resource access rules and they also possibly have fewer encounters with the PTR authorities. This finding concurs with other research reporting conservation knowledge to be inversely associated with a residence distance from a PA (Ormsby and Kaplin 2005; Olomí-Solà et al. 2012).

Both JFM and ED are designed as participatory projects. Nevertheless, both of them are implemented in a top-down way with passive engagement of participants (Hildyard 
et al. 2001; Tiger Task Force 2005). Moreover, villagers frequently identify the ED project with the actual MPFD, where ED is seen as a one more way of forest access control (Interview, local NGO member, March 2014; also in Read 2015; Sarin et al. 2003). Scholars have interpreted such types of participatory projects as a state-driven territorialization (Véron and Fehr 2011) and "recentralizing while decentralizing" (Ribot et al. 2006). This perception of control and reluctance of the forest department to give real power to locals can be possibly explained with the internal organizational structure and working culture of the forest department. The forest department is responsible to implement participatory strategies when, at the same time, a strong sense of hierarchy is present within their own organization (Lawrence 2007; Fleischman 2015; Guha 1997). According to Vemuri (2008), attitudinal changes of forest department staff to prepare for the policy that advocates social inclusion into the hierarchical system of forest management did not happen. As the forest department staff frequently lacks time and adequate training for implementing the participatory activities, these initiatives are never truly institutionalized (Fleischman 2015). Moreover, changing from being an enforcement officer to someone who has also to "talk to and drink tea together with the villagers" is often an uneasy task (Interview, PTR lower level forest officer-wildlife wing, March 2014).

Although ED and JFM are designed to create people's support for conservation and manage conflicts, data from qualitative interviews show that these projects may even have negative social impacts. Village and household benefits and provisions used to be more abundant under IEDP, but are now limited. This might have raised disappointments among locals. Moreover, qualitative data also showed that EDC meetings, that are supposedly arenas to negotiate benefits with MPFD or to make resource management decisions, are nowadays either non-existent or very rare in both JFM and ED. When funding is available, provisions are distributed (once per year/2 years) in a topdown way and local demands (for example, fences against crop raiding) are often not fulfilled. Moreover, when benefits are available, internal conflicts may increase among locals, as there are not enough provisions for everyone in the village (e.g. 10 gas cylinders per a village of 300 households) (Informal interview, villager, January 2014). Since EDC members are intermediaries between local people and MPFD, they are often blamed for unfulfilled demands or unequal distribution of benefits (Interview, EDC member, January 2014), which may translate into intra-community conflicts.

Giving incentives can change people's conservation values, as it has been observed in other cases (GarcíaAmado et al. 2013). However, if not executed properly and without active local participation, incentive-based conservation can exacerbate local conflicts and existing social differences, prompting the capture of benefits by local elites, excluding the poor and marginalized parts of the society (Balooni et al. 2010), instead of creating positive behavioural changes towards conservation.

\section{Conclusions}

Lessons learned from evaluating interventions that may affect the conservation success, create local support and mediate human-wildlife conflicts around tiger reserves can be critical for the effective tiger conservation. According to the recent tiger census from 2014 (Jhala et al. 2015), the tiger population increased in India by $30.5 \%$ (this increase was also recorded in Madhya Pradesh). However, threats to tigers are still intensifying (Wikramanayake et al. 2010), especially outside of PA networks. Due to lack of space for both tigers and humans, this increase in the tiger population might also mean more human-wildlife conflicts (Rastogi et al. 2012; Read 2015). Therefore, it is important to know which interventions can generate local people's support for conservation efforts and under which conditions.

In this study, we measured impacts of top-down stateinduced participation on selected social outcomes, and we found negligible effects. Our findings thus indicate that the effectiveness of participatory conservation interventions is conditional upon the level and nature of local participation.

Ever since 2004 and the local extinction of tigers in Sariska, and later in Panna Tiger reserve, active social inclusion and more attention to the local context are recognized to be of high importance for conservation and long-lasting efforts to secure tiger survival (Tiger Task Force 2005). A decade later, our findings, in line with the other literature on the topic, suggest that strong participatory rhetoric of the policies has not yet translated into practice and that externally induced, top-down participation does not produce desired effects. This inertia might be approached with the internal structural changes and decentralization of the management agency, as their outdated training and historical role in exclusive policy enforcement may not leave much space for active inclusion of local people in forest conservation and management (Lawrence 2007).

Acknowledgments We are grateful to the people from 16 villages for their precious time and participation in this research and to the PTR field director, deputy director, and the staff for their generous help during the fieldwork. Thanks to the Dean and Director of Wildlife Institute of India, Dehradun for facilitating this research and to the Madhya Pradesh Forest Department for granting the research permits. Special thanks to Ishteyaque Ahmad Patel, Shivaji Chavan, TRIPS and five excellent enumerators. The manuscript benefited from comments of Neal Hockley, Davide Pettenella and Maria Sassi and 24th IUFRO World congress participants (October 2014, USA). We 
are grateful to Trishna Dutta and anonymous reviewers for suggestions that significantly improved the original manuscript. BM is very grateful to Ivana Logar, Elisabeth Gsottbauer, Habtamu Tilahun Kassahun, Paul Woodcock and Riccardo Da Re for critical comments and suggestions during various phases of this research. BM acknowledges a doctoral research Grant from the Forest and Nature for Society (FONASO) Erasmus Mundus consortium.

\section{Compliance with ethical standards}

This research has been approved by the Ethics Committee of the College of Natural Sciences, Bangor University.

Open Access This article is distributed under the terms of the Creative Commons Attribution 4.0 International License (http://crea tivecommons.org/licenses/by/4.0/), which permits unrestricted use, distribution, and reproduction in any medium, provided you give appropriate credit to the original author(s) and the source, provide a link to the Creative Commons license, and indicate if changes were made.

\section{References}

Agarwal B (2001) Participatory exclusions, community forestry, and gender: an analysis for South Asia and a conceptual framework. World Dev 29:1623-1648. doi:10.1016/S0305-750X(01)000663

Ajzen I (2001) Nature and operation of attitudes. Annu Rev Psychol 52:27-58. doi:10.1146/annurev.psych.52.1.27

Allendorf TD, Allendorf K (2013) Gender and attitudes toward protected areas in Myanmar. Soc Nat Resour 26:962-976. doi:10.1080/08941920.2012.729295

Ameha A, Nielsen OJ, Larsen HO (2014) Impacts of access and benefit sharing on livelihoods and forest: case of participatory forest management in Ethiopia. Ecol Econ 97:162-171. doi:10. 1016/j.ecolecon.2013.11.011

Andrade GSM, Rhodes JR (2012) Protected areas and local communities: an inevitable partnership toward successful conservation strategies? Ecol Soc 17:14. doi:10.5751/ES-05216-170414

Arjunan M, Holmes C, Puyravaud J-P, Davidar P (2006) Do developmental initiatives influence local attitudes toward conservation? A case study from the Kalakad-Mundanthurai Tiger Reserve, India. J Environ Manage 79:188-197. doi:10.1016/j. jenvman.2005.06.007

Arnstein S (1969) A ladder of citizen participation. J Am Inst Plann 35:216-224. doi:10.1080/01944366908977225

Badola R (2000) Local people amidst the changing conservation ethos: relationships between people and protected areas in India. In: Enters T, Drust PB, Victor M (eds) Decentralization and devolution of forest management in Asia and the Pacific. RECOFTC report no. 18 and RAP Publication 2000/1, Bangkok, pp 187-204

Balooni K, Lund JF, Kumar C, Inoue M (2010) Curse or blessing? Local elites in Joint Forest Management in India's Shiwaliks. Int J Commons 4:707-728. doi:10.18352/ijc.217

Baral N (2012) Empirical analysis of factors explaining local governing bodies' trust for administering agencies in community-based conservation. Environ Manage 103:41-50. doi:10. 1016/j.jenvman.2012.02.031

Baral N, Heinen JT (2007) Decentralization and people's participation in conservation: a comparative study from the Western Terai of Nepal. Int J Sustain Dev World Ecol 14:520-531. doi:10. 1080/13504500709469751
Bauch SC, Sills EO, Pattanayak SK (2014) Have we managed to integrate conservation and development? ICDP impacts in the Brazilian Amazon. World Dev 64:S135-S148. doi:10.1016/j. worlddev.2014.03.009

Berkes F (2009) Evolution of co-management: role of knowledge generation, bridging organizations and social learning. Environ Manage 90:1692-1702. doi:10.1016/j.jenvman.2008.12.001

Bernard HR (2006) Research methods in anthropology. Qualitative and quantitative approaches, 4th edn. AltaMira Press, Oxford

Bhattacharya P, Pradhan L, Yadav G (2010) Joint forest management in India: experiences of two decades. Resour Conserv Recycl 54:469-480. doi:10.1016/j.resconrec.2009.10.003

Brechin SR, Wilshusen PR, Fortwangler CL, West PC (2002) Beyond the square wheel: toward a more comprehensive understanding of biodiversity conservation as social and political process. Soc Nat Resour 15:41-64. doi:10.1080/089419202317174011

Caliendo M, Kopeinig S (2008) Some practical guidance for the implementation of propensity score matching. J Econ Surv 22:31-72. doi:10.1111/j.1467-6419.2007.00527.x

Census of India (2011) List of villages/towns. http://www.censusin dia.gov.in/(S(thfeo255jrszfnbr10h3bzfr))/2011census/Listofvilla gesandtowns.aspx. Accessed 18 Dec 2014

Damodaran A, Engel S (2003) Joint Forest Management in India: assessment of performance and evaluation of impacts. ZEFdiscussion papers on development policy no. 77, October 2003, Center for Development Research, Bonn

Dejouhanet L (2010) Participatory eco-development in question: the case of the Parambikulam wildlife sanctuary in South India. J Alp Res 98:83-96

Dugoff EH, Schuler M, Stuart EA (2014) Generalizing observational study results: applying propensity score methods to complex surveys. Health Serv Res 49:284-303. doi:10.1111/1475-6773. 12090

Ferraro PJ (2012) Experimental project designs in the Global Environmental Facility: designing projects to create evidence and catalyze investments to secure global environmental benefits. Global Environment Facility/United Nations Environment Programme, Washington, DC

Ferraro PJ, Miranda JJ (2014) The performance of non-experimental designs in the evaluation of environmental programs: a designreplication study using a large-scale randomized experiment as a benchmark. J Econ Behav Organ. doi:10.1016/j.jebo.2014.03.008

Fleischman F (2015) Understanding India's forest bureaucracy: a review. Reg Environ Change. doi:10.1007/s10113-015-0844-8

García-Amado L, Ruiz Pérez M, Barrasa García S (2013) Motivation for conservation: assessing integrated conservation and development projects and payments for environmental services in La Sepultura Biosphere Reserve, Chiapas, Mexico. Ecol Econ 89:92-100. doi:10.1016/j.ecolecon.2013.02.002

Glaser M, Wasistini B, Ferse SCA, Neil M, Deswandi R (2010) Whose sustainability? Top-down participation and emergent rules in marine protected area management in Indonesia. Mar Policy 34:1215-1225. doi:10.1016/j.marpol.2010.04.006

Government of India (1988) The National Forest Policy, resolution no. 3-1/86-FP. 10

Gubbi S, Linkie M, Leader-Williams N (2008) Evaluating the legacy of an integrated conservation and development project around a tiger reserve in India. Environ Conserv 35:331-339. doi:10. 1017/S0376892908005225

Guha R (1997) The authoritarian biologist and the arrogance of antihumanism. Ecologist 27:14-21

Heckman J, Ichimura H, Smith J, Todd P (1998) Characterizing selection bias using experimental data. Econometrica 66:1017-1098. doi:10.2307/2999630

Hegde R, Bull GQ (2011) Performance of an agro-forestry based payments-for-environmental-services project in Mozambique: a 
household level analysis. Ecol Econ 71:122-130. doi:10.1016/j. ecolecon.2011.08.014

Hildyard N, Hegde P, Wolvekamp P, Reddy S (2001) Pluralism, participation and power: joint forest management in India. In: Cooke B, Kothari U (eds) Particip. New tyranny?. Zed Books, London, pp 56-71

Jhala YV, Qureshi Q, Gopal R (2015) Status of tigers in India, 2014. National Tiger Conservation Authority, New Delhi and The Wildlife Institute of India, Dehradun

Jumbe C, Angelsen A (2006) Do the poor benefit from devolution policies? Evidence from Malawi's forest co-management program. Land Econ 82:562-581. doi:10.3368/le.82.4.562

Kumar S (2002) Does "participation" in common pool resource management help the poor? A social cost-benefit analysis of Joint Forest Management in Jharkhand, India. World Dev 30:763-782. doi:10.1016/S0305-750X(02)00004-9

Kumar K, Singh NM, Kerr JM (2014) Decentralisation and democratic forest reforms in India: moving to a rights-based approach. For Policy Econ. doi:10.1016/j.forpol.2014.09.018

Lawrence A (2007) Beyond the second generation: towards adaptiveness in participatory forest management. CAB Rev Perspect Agric Vet Sci Nutr Nat Resour 2:1-15. doi:10.1079/ PAVSNNR20072028

Lund JF, Balooni K, Casse T (2009) Change we can believe in? Reviewing studies on the conservation impact of popular participation in forest management. Conserv Soc 7:71-82. doi:10.4103/0972-4923.58640

Macura B, Zorondo-Rodríguez F, Grau-Satorras M, Demps K, Laval M, Garcia CA, Reyes-García V (2011) Local community attitudes toward forests outside protected areas in India: impact of legal awareness, trust and participation. Ecol Soc 16:10. doi: $10.5751 /$ ES-04242-160310

Madhya Pradesh Forest Department (2014) Joint Forest Management. http://www.mpforest.org/jointforestmanagement.html\#8. Accessed 18 Dec 2014

Mahanty S (2002) Conservation and development interventions as networks: the case of the India ecodevelopment project, Karnataka. World Dev 30:1369-1386. doi:10.1016/S0305750X(02)00039-6

Mansuri G, Rao V (2013) Localizing development: does participation work?. World Bank Publications, Washington, DC

Ministry of Environment and Forests (MOEF) (2007) Guidelines to notify critical wildlife habitat including constitution and functions of Expert Committee, scientific information required and resettlement and matters incidental thereto. Government of India, New Delhi

Miteva D, Pattanayak SK, Ferraro PJ (2012) Evaluation of biodiversity policy instruments: what works and what doesn't? Oxford Rev Econ Policy 28:69-92. doi:10.1093/oxrep/grs009

Morgan-Brown T, Jacobson SK, Wald K, Child B (2010) Quantitative assessment of a Tanzanian integrated conservation and development project involving butterfly farming. Conserv Biol 24:563-572. doi:10.1111/j.1523-1739.2009.01433.x

Murali KS, Rao RJ, Ravindranath NH (2002) Evaluation studies of Joint Forest Management in India: a review of analytical processes. Int J Environ Sustain Dev 1:184-199

Nayak PK, Berkes F (2008) Politics of co-optation: community forest management versus Joint Forest Management in Orissa, India. Environ Manage 41:707-718. doi:10.1007/s00267-008-9088-4

Olomí-Solà M, Zorondo-Rodríguez F, Triguero-Mas M et al (2012) Local residents' knowledge about protected areas: a case study in Dandeli Wildlife sanctuary, India. Soc Nat Resour 25:410-420. doi:10.1080/08941920.2011.591034

Ormsby A, Kaplin BA (2005) A framework for understanding community resident perceptions of Masoala National Park,
Madagascar. Environ Conserv 32:156-164. doi:10.1017/ S0376892905002146

Ostrom E (1990) Governing the commons: the evolution of institutions for collective action. Cambridge University Press, Cambridge

Panigrahi R (2006) Democratization of forest governance: Myths and realities (an analysis of implications of decentralized forest policies and processes in Orissa, India). In: Eleventh biennial conference of the international association for the study of common property. 19-23 June 2006, Bali, Indonesia

Pench Tiger Reserve (2012) Welcome to PTR. Unpublished internal presentation

Persha L, Agrawal A, Chhatre A (2011) Social and ecological synergy: local rulemaking, forest livelihoods, and biodiversity conservation. Science 331:1606-1608. doi:10.1126/science. 1199343

Pimbert M, Pretty J (1995) Parks, people, and professionals. Putting 'participation' into protected area management. UNRISD discussion paper no. 57, Geneva

Pirracchio R, Resche-Rigon M, Chevret S (2012) Evaluation of the propensity score methods for estimating marginal odds ratios in case of small sample size. BMC Med Res Methodol 12:70. doi:10.1186/1471-2288-12-70

Pretty JN (1995) Participatory learning for sustainable agriculture. World Dev 23:1247-1263. doi:10.1016/0305-750X(95)00046-F

Rastogi A, Hickey GM, Gordon M, Badola R, Hussain SA (2012) Saving the superstar: a review of the social factors affecting tiger conservation in India. J Environ Manage 113:328-340. doi:10. 1016/j.jenvman.2012.10.003

Rastogi A, Thapliyal S, Hickey GM (2014) Community action and tiger conservation: assessing the role of social capital. Soc Nat Resour. doi:10.1080/08941920.2014.917753

Read D (2015) Legitimacy, access, and the gridlock of tiger conservation: lessons from Melghat and the history of central India. Reg Environ Chang. doi:10.1007/s10113-015-0780-7

Reed MS (2008) Stakeholder participation for environmental management: a literature review. Biol Conserv 141:2417-2431. doi:10.1016/j.biocon.2008.07.014

Reyes-Garcia V, Ruiz-Mallen I, Porter-Bolland L et al (2013) Local understandings of conservation in southeastern Mexico and their implications for community-based conservation as an alternative paradigm. Conserv Biol 27:856-865. doi:10.1111/ cobi. 12056

Ribot JC, Agrawal A, Larson AM (2006) Recentralizing while decentralizing: how national governments reappropriate forest resources. World Dev 34:1864-1886. doi:10.1016/j.worlddev. 2005.11.020

Richards C, Blackstock KL, Carter CE (2004) Practical approaches to participation. SERG Policy brief no. 1. Macauley land use research institute, Aberdeen

Rosenbaum P, Rubin D (1983) The central role of the propensity score in observational studies for causal effects. Biometrika 70:41-55. doi:10.1093/biomet/70.1.41

Sarin M, Singh NM, Sundar N, Bhogal RK (2003) Devolution as a threat to democratic decision-making in forestry? Findings from three states in India. In: Edmunds D, Wollenberg E (eds) Local forest management: the impacts of devolution policies. Earthscan, London, pp 55-126

Schultz WP (2002) Knowledge, information, and household recycling: examining the knowledge-deficit model of behavior change. In: Dietz T, Stern PC (eds) New tools for environmental protection: education, information and voluntary measures. Committee on the Human Dimensions of Global Change, National Research Council. National Academy Press, Washington DC, pp 67-82 
Shyamsundar P, Ghate R (2014) Rights, rewards, and resources: lessons from community forestry in South Asia. Rev Environ Econ Policy 8:80-102. doi:10.1093/reep/ret022

Singh VRR, Mishra D, Dhawan VK (2011) Status of Joint Forest Management in India (as on June 2011). In: Proceedings of national workshop on JFM 27-28 June 2011. FRI-ICFRE, pp 1-74

St. John FAV, Edwards-Jones G, Jones JPG (2010) Conservation and human behaviour: lessons from social psychology. Wildl Res 37:658-667. doi:10.1071/WR10032

Tiger Task Force (2005) Joining the dots-the report of the Tiger Task Force, Ministry of Environment and Forests. Government of India, New Delhi

Vemuri A (2008) Joint Forest Management in India: an unavoidable and conflicting common property regime in natural resource management. J Dev Soc Transform 5:81-90

Véron R, Fehr G (2011) State power and protected areas: dynamics and contradictions of forest conservation in Madhya Pradesh, India. Polit Geogr 30:282-293. doi:10.1016/j.polgeo.2011.05. 004

Weber J, Sills E, Bauch S, Pattanayak S (2011) Do ICDPs work? An empirical evaluation of forest-based microenterprises in the Brazilian Amazon. Land Econ 87:661-681. doi:10.3368/le.87.4. 661
White SC (1996) Depoliticising development: the uses and abuses of participation. Dev Pract 6:6-15. doi:10.1080/ 0961452961000157564

Wikramanayake E, Dinerstein E, Forest J, Loucks C, Seidensticker J, Klenzendorf S, Sanderson EW, Simons R, Heydlauff A, Ginsberg J, O'Brien T, Leimgruber P, Songer M, Bryja G (2010) Roads to recovery or catastrophic loss: how will the next decade end for wild tigers. In: Tilson R, Nyhus P (eds) Tigers of the world: the science, politics, and conservation of Panthera tigris, 2nd edn. Elsevier/Academic Press, Oxford, pp 493-503

Woodman J (2002) Ghosts in the transmission: the translation of global conservation concepts to local scenarios-a case study of ecodevelopment in central India. In: 9th Biennial conference of the IASCP: the commons in an age of globalisation, pp 1-30

World Bank (2007) Project performance assessment report: India Ecodevelopment project (Credit 2916-IN). Report no.: 39930. Sector, thematic and global evaluation division independent evaluation group

Young JC, Jordan A, Searle KR, Butler A, Chapman DS, Simmons P, Watt AD (2013) Does stakeholder involvement really benefit biodiversity conservation? Biol Conserv 158:359-370. doi:10. 1016/j.biocon.2012.08.018 